\title{
mRNA expression levels of hypoxia-induced and stem cell-associated genes in human glioblastoma
}

\author{
MATTHIAS BACHE ${ }^{1}$, SWETLANA ROT ${ }^{1,2}$, JACQUELINE KESSLER ${ }^{1}$, ANTJE GÜTTLER ${ }^{1}$, \\ HENRI WICHMANN $^{1,2}$, THOMAS GREITHER ${ }^{3}$, SVEN WACH $^{4}$, HELGE TAUBERT ${ }^{4}$, \\ ARIANE SÖLING $^{5}$, UDO BILKENROTH ${ }^{6}$, MATTHIAS KAPPLER $^{2}$ and DIRK VORDERMARK ${ }^{1}$ \\ ${ }^{1}$ Department of Radiotherapy, ${ }^{2}$ Department of Oral and Maxillofacial Plastic Surgery and \\ ${ }^{3}$ Center for Reproductive Medicine and Andrology, Martin Luther University Halle-Wittenberg, Halle; \\ ${ }^{4}$ Clinic of Urology, Friedrich Alexander University Erlangen-Nürnberg, Erlangen; \\ ${ }^{5}$ Department of Pediatrics, University of Göttingen, Göttingen; ${ }^{6}$ Institute of Pathology, Eisleben, Germany
}

Received February 16, 2015; Accepted March 24, 2015

DOI: 10.3892/or.2015.3932

\begin{abstract}
The roles of hypoxia-induced and stem cell-associated genes in the development of malignancy and tumour progression are well known. However, there are a limited number of studies analysing the impact of mRNA expression levels of hypoxia-induced and stem cell-associated genes in the tissues of brain tumours and glioblastoma patients. In this study, tumour tissues from patients with glioblastoma multiforme and tumour adjacent tissues were analysed. We investigated mRNA expression levels of hypoxia-inducible factor- $1 \alpha$ (HIF-1 $\alpha$ ), hypoxia-inducible factor- $2 \alpha$ (HIF- $2 \alpha$ ), carbonic anhydrase 9 (CA9), vascular endothelial growth factor (VEGF), glucose transporter-1 (GLUT-1) and osteopontin (OPN), and stem cell-associated genes survivin, epidermal growth factor receptor (EGFR), human telomerase reverse transcriptase (hTERT), Nanog and octamer binding transcription factor 4 (OCT4) using quantitative real-time polymerase chain reaction (qRT-PCR). Our data revealed higher mRNA expression levels of hypoxia-induced and stem cell-associated genes in tumour tissue than levels in the tumour adjacent tissues in patients with glioblastoma multiforme. A strong positive correlation between the mRNA expression levels of HIF-2 $\alpha$, CA9, VEGF, GLUT-1 and OPN suggests a specific hypoxia-associated profile of mRNA expression in glioblastoma multiforme. Additionally, the results indicate the role of stem-cell-related genes in tumour hypoxia. Kaplan-Maier analysis revealed that high mRNA expression levels of hypoxia-induced markers showed a trend towards shorter overall survival in glioblastoma patients $(\mathrm{P}=0.061)$. Our
\end{abstract}

Correspondence to: Dr Matthias Bache, Department of Radiotherapy, Faculty of Medicine, Martin-Luther-University Halle-Wittenberg, Ernst-Grube-Str. 40, D-06097 Halle/Saale, Germany

E-mail: matthias.bache@medizin.uni-halle.de

Key words: glioblastoma, hypoxia-induced and stem cell-associated genes, mRNA expression data suggest that mRNA expression levels of hypoxia-induced genes are important tumour markers in patients with glioblastoma multiforme.

\section{Introduction}

Glioblastoma multiforme is the most common malignant brain tumour and is characterised by a poor prognosis. Glioblastomas often can only be resected partially and a cure is not possible. The treatment for glioblastoma consists mostly of surgery and subsequent radiotherapy with concomitant and sequential chemotherapy. However, despite multimodal treatment, the median overall survival of approximately 10-15 months is still very short (1-3).

Hypoxia is the lack of oxygen, and it is an important factor that reduces the tumour response to radiation and chemotherapy. In addition, tumour hypoxia promotes mutagenesis and leads to genetic instability and clonal expansion of aggressive tumour cell types (4). Numerous studies have shown that hypoxic tumours have a more aggressive phenotype (5). Most high-grade gliomas have hypoxic regions (6). Furthermore, it has been suggested that hypoxia is responsible for malignant progression and the development of 'cancer stem cells' in gliomas (7). In vitro analyses revealed that low oxygen levels induced expression of stem cell-associated markers (8-11). It is well known that 'cancer stem cells' in particular are resistant to radiation and chemotherapy.

The prognostic significance of tumour hypoxia markers has been demonstrated in various solid tumours such as head and neck cancer, cervical, breast and prostate cancer, soft tissue sarcoma, melanoma, and glioblastoma $(12,13)$. Furthermore, the contribution of cancer stem cells to the prognosis of glioma patients has been recently discussed (14). There are several therapeutic strategies that affect the expression levels of hypoxia-induced and stem cell-associated genes in glioma $(15,16)$. The impact of mRNA expression levels of hypoxia-induced and stem cell-associated genes in tumour tissue from glioblastoma patients has been insufficiently characterised. However, the most statistically significant gene set identified in a meta-analysis was the hypoxia-inducible 
factor (HIF) pathway, which has been repeatedly implicated in glioblastoma (17). In the present study, we determined the impact of mRNA expression levels of different hypoxia-induced [hypoxia-inducible factor- $1 \alpha$ (HIF-1 $\alpha)$, hypoxia-inducible factor- $2 \alpha$ (HIF- $2 \alpha$ ), carbonic anhydrase 9 (CA9), vascular endothelial growth factor (VEGF), glucose transporter-1 (GLUT-1) and osteopontin (OPN)], and stem cell-associated genes [(survivin, epidermal growth factor receptor (EGFR), human telomerase reverse transcriptase (hTERT), Nanog and octamer-binding transcription factor 4 (OCT4)] that were quantified by quantitative real-time polymerase chain reaction (qRT-PCR) in tumour tissues from patients with glioblastoma. In addition to classical stem cell genes (Nanog and OCT4), mRNA expression levels of inhibitor-of-apoptosis protein survivin, the EGFR, and the catalytic subunit of telomerase hTERT were determined. The association of survivin, EGFR and hTERT in stem cells and/or cancer cells is well discussed. Recently, studies suggest that regulation of expression levels of these stem cell-associated genes is important for the development of glioma stem cells (18-23). In addition, there are first indications, that the analysed stem cell-associated genes are upregulated also by hypoxia.

\section{Materials and methods}

Patients and tumour material. Pre-therapeutic tumour samples from 34 patients (treated from 1999 to 2004) with primary glioblastoma and 7 samples of brain tissue adjacent to malignant glioma were analysed in this study. The tumours were classified according to the World Health Organisation guidelines.

Tissue was collected following surgical resection and snap-frozen in liquid nitrogen prior to RNA extraction. The patients in this study have been partially described previously (24). Clinical data, treatment and tumour characteristics were recorded (Table I). The median patient age was 63 years, and the patient ages ranged from 27 to 78 years. There were 16 male and 18 female patients in this study. The median overall survival time was 9.8 months (0.7-47 months). The study was performed in compliance with the Helsinki Declaration and was approved by the Ethics Committee of the Medical Faculty of the University of Halle.

Reverse transcription- and quantitative real-time PCR (qRT-PCR). Total RNA from the glioblastoma tissue samples was isolated by the TRIzol method (Invitrogen, Karlsruhe, Germany) according to the manufacturer's instructions. For cDNA synthesis we used $1 \mu \mathrm{g}$ of RNA in a 'RevertAid H-Minus' First Strand cDNA Synthesis kit (Fermentas, Waltham, MA, USA) as described in the manufacturer's instructions. For qRT-PCR, $1 \mu \mathrm{l}$ of cDNA was added to the Maxima SYBR Green/ROX qPCR Master Mix (2X), with $20 \mu \mathrm{M}$ PCR primers (Table II) and distilled water according to the manufacturer's instructions (Fermentas/Thermo Fisher Scientific, Inc.). The qRT-PCR reaction was performed on a Rotor-Gene 6000 (Qiagen, Hilden, Germany) as previously described (25). The PCR cycling included incubation for $15 \mathrm{~min}$ at $95^{\circ} \mathrm{C}$, followed by 40 cycles of the following: $30 \mathrm{sec}$ at $95^{\circ} \mathrm{C}, 30 \mathrm{sec}$ at the specific annealing temperature (Table II) and $30 \mathrm{sec}$ at $72^{\circ} \mathrm{C}$. A melting curve analysis in the
Table I. Clinical characteristics of the patients with glioblastoma.

\begin{tabular}{|c|c|c|}
\hline Characteristics & $\mathrm{N}$ & $\%$ \\
\hline \multicolumn{3}{|l|}{ Age (years) } \\
\hline$<60$ & 10 & 29.4 \\
\hline$\geq 60$ & 24 & 70.6 \\
\hline \multicolumn{3}{|l|}{ Gender } \\
\hline Male & 16 & 47.1 \\
\hline Female & 18 & 52.9 \\
\hline \multicolumn{3}{|l|}{ Localization } \\
\hline Frontal & 7 & 20.6 \\
\hline Parietal & 5 & 14.7 \\
\hline Temporal & 13 & 38.2 \\
\hline Occipital & 3 & 8.8 \\
\hline Other & 2 & 5.9 \\
\hline Not available & 4 & 11.8 \\
\hline \multicolumn{3}{|l|}{ Resection } \\
\hline Total & 14 & 41.2 \\
\hline Partial & 16 & 47.1 \\
\hline Not available & 4 & 11.8 \\
\hline \multicolumn{3}{|c|}{ Radiotherapy (median dose: 45 Gy) } \\
\hline Yes & 23 & 67.6 \\
\hline No & 11 & 32.4 \\
\hline \multicolumn{3}{|c|}{ Chemotherapy (BCNU or hydroxyurea) } \\
\hline Yes & 19 & 55.9 \\
\hline No & 15 & 44.1 \\
\hline
\end{tabular}

temperature range of $65-95^{\circ} \mathrm{C}\left(5^{\circ} \mathrm{C} / \mathrm{sec}\right)$ was performed. Three genes were used as reference: RNA polymerase II (RPII), glyceraldehyde-3-phosphate dehydrogenase (GAPDH) and hypoxanthine-guanine phosphoribosyl transferase (HPRT). Based on the NormFinder software, RPII was the most stably expressed gene in glioblastoma tissue. The expression levels of hypoxia-induced or stem cell-associated genes were quantified as (specific) mRNA copies/RPII mRNA copies.

Statistical methods. All statistical analyses were performed with the SPSS v.19 software package for Windows (SPSS Inc., Chicago, IL, USA). The differences in the numerical data between glioblastoma tissue and tumour adjacent tissue were evaluated using the Mann-Whitney U test. Bivariate correlation analyses were performed by Spearman's rank correlation test. The mRNA expression levels were stratified according to the median into low and high expression groups for each analysed gene. These expression groups were associated with clinicopathological parameters in cross-classified tables (Chi-square test). For survival analyses the overall survival of patients was used as the end point. The survival curves were generated using Kaplan-Meier analysis, and the log-rank test was applied to test for differences. For further univariate analyses, the Cox's proportional-hazards regression model was used to calculate the hazard ratio in the survival analysis. A P-value of $<0.05$ was considered to indicate a statistically significant result. 
Table II. Gene name, primer, annealing temperature, NCBI number and primer localization for qRT-PCR.

\begin{tabular}{|c|c|c|c|c|c|}
\hline Genes & Gene name & Primer & $\begin{array}{c}\text { Annealing } \\
\text { temperature }\left({ }^{\circ} \mathrm{C}\right)\end{array}$ & NCBI number & $\begin{array}{c}\text { Primer } \\
\text { localization }\end{array}$ \\
\hline \multirow[t]{3}{*}{ Reference } & HPRT & $\begin{array}{l}\text { Sense } \\
\text { Antisense }\end{array}$ & 60 & NM_000194.2 & $\begin{array}{l}\text { fw } 391-410 \\
\text { rev } 652-633\end{array}$ \\
\hline & GAPDH & $\begin{array}{l}\text { Sense } \\
\text { Antisense }\end{array}$ & 58 & NM_002046.5 & $\begin{array}{l}\text { fw } 1055-1074 \\
\text { rev } 1164-1145\end{array}$ \\
\hline & RPII & $\begin{array}{l}\text { Sense } \\
\text { Antisense }\end{array}$ & 60 & NM_000937.4 & $\begin{array}{l}\text { fw } 1358-1377 \\
\text { rev } 1440-1421\end{array}$ \\
\hline \multirow[t]{6}{*}{ Hypoxia } & HIF-1 $\alpha$ & $\begin{array}{l}\text { Sense } \\
\text { Antisense }\end{array}$ & 60 & NM_001530.3 & $\begin{array}{l}\text { fw } 1309-1330 \\
\text { rev } 1406-1384\end{array}$ \\
\hline & HIF-2 $\alpha$ & $\begin{array}{l}\text { Sense } \\
\text { Antisense }\end{array}$ & 60 & NM_001430.4 & $\begin{array}{l}\text { fw } 2521-2540 \\
\text { rev } 2737-2718\end{array}$ \\
\hline & VEGF & $\begin{array}{l}\text { Sense } \\
\text { Antisense }\end{array}$ & 60 & NM_001171623.1 & $\begin{array}{l}\text { fw } 1087-1106 \\
\text { rev } 1149-1129\end{array}$ \\
\hline & CA9 & $\begin{array}{l}\text { Sense } \\
\text { Antisense }\end{array}$ & 60 & NM_001216.2 & $\begin{array}{l}\text { fw } 752-772 \\
\text { rev } 880-861\end{array}$ \\
\hline & GLUT-1 & $\begin{array}{l}\text { Sense } \\
\text { Antisense }\end{array}$ & 60 & NM_006516.2 & $\begin{array}{l}\text { fw } 1483-1503 \\
\text { rev } 1589-1570\end{array}$ \\
\hline & OPN & $\begin{array}{l}\text { Sense } \\
\text { Antisense }\end{array}$ & 60 & NM_001040058.1 & $\begin{array}{l}\text { fw } 610-629 \\
\text { rev } 758-739\end{array}$ \\
\hline \multirow[t]{5}{*}{ Stem cell } & EGFR & $\begin{array}{l}\text { Sense } \\
\text { Antisense }\end{array}$ & 60 & NM_005228.3 & $\begin{array}{l}\text { fw } 2455-2481 \\
\text { rev 2542-2518 }\end{array}$ \\
\hline & Survivin & $\begin{array}{l}\text { Sense } \\
\text { Antisense }\end{array}$ & 60 & NM_001168.2 & $\begin{array}{l}\text { fw 182-203 } \\
\text { rev 283-262 }\end{array}$ \\
\hline & hTERT & $\begin{array}{l}\text { Sense } \\
\text { Antisense }\end{array}$ & 60 & NM_198253.2 & $\begin{array}{l}\text { fw 1787-1806 } \\
\text { rev 1931-1913 }\end{array}$ \\
\hline & Nanog & $\begin{array}{l}\text { Sense } \\
\text { Antisense }\end{array}$ & 60 & NM_024865.2 & $\begin{array}{l}\text { fw } 343-363 \\
\text { rev } 505-483\end{array}$ \\
\hline & OCT4 & $\begin{array}{l}\text { Sense } \\
\text { Antisense }\end{array}$ & 63 & NM_002701.5 & $\begin{array}{l}\text { fw } 446-466 \\
\text { rev } 629-607\end{array}$ \\
\hline
\end{tabular}

HIF-1 $\alpha$, hypoxia-inducible factor-1 $\alpha$; HIF- $2 \alpha$, hypoxia-inducible factor-2 $\alpha$; CA9, carbonic anhydrase 9; VEGF, vascular endothelial growth factor; GLUT-1, glucose transporter-1; OPN, osteopontin; EGFR, epidermal growth factor receptor; hTERT, human telomerase reverse transcriptase; OCT4, octamer-binding transcription factor 4; RPII, RNA polymerase II; GAPDH, glyceraldehyde-3-phosphate dehydrogenase; HPRT, hypoxanthine-guanine phosphoribosyl transferase.

\section{Results}

mRNA expression levels of hypoxia-induced and stem cell-associated genes in glioblastoma. The mRNA expression levels of all hypoxia-induced and stem cell-associated genes in tumour tissues from glioblastoma patients $(n=34)$ were higher than in tumour adjacent brain tissues $(n=7)$. A significant difference was detected with respect to hypoxia-induced genes HIF-2 $\alpha$, CA9 and VEGF, and stem cell-associated genes hTERT and OCT4 (Table III). However, the other hypoxia-induced and stem cell-associated genes did not have significant differential expression.

There was a significant association in bivariate analysis (Spearman's rho test) between mRNA expression levels of the hypoxia-induced genes CA9, HIF-2 $\alpha$ and GLUT-1 with OPN, a marker of migration and metastasis. Furthermore, the expression of HIF- $1 \alpha$ and HIF- $2 \alpha$ correlated positively with the stem cell-related gene EGFR. Additionally, the expression of HIF-1 $\alpha$ was associated with the expression of the stem cell-associated gene survivin (Table IV). Altogether, our results suggest a distinct hypoxic mRNA profile for glioblastoma. We also found correlations between mRNA levels of stem cell-associated genes. EGFR transcript levels showed a significant positive correlation with survivin, and Nanog mRNA expression was significantly associated with OCT4 expression. However, expression of stem cell-associated and hypoxia-induced genes did not correlate with mRNA levels of hTERT (Table IV).

Association of hypoxia-induced and stem cell-associated gene mRNA levels with clinical characteristics and survival. Based on the median values, we found associations of hypoxia-induced and stem cell-associated gene expression levels with age and gender. Females $(n=18)$ showed higher mRNA expression levels of the hypoxia-induced markers VEGF $(\mathrm{P}=0.039)$ and CA9 $(\mathrm{P}=0.039)$, and higher expression of the stem cell-associated genes Nanog $(\mathrm{P}=0.039)$ and OCT4 $(\mathrm{P}=0.015)$ than men $(\mathrm{n}=16)$. 
Table III. Mean and median mRNA expression levels of hypoxia-induced and stem cell-associated genes in tumour adjacent tissues and glioblastomas.

\begin{tabular}{|c|c|c|c|c|}
\hline Gene name & Tissue & $\begin{array}{l}\text { Mean mRNA level } \\
\text { in copies/copies RPII }\end{array}$ & $\begin{array}{l}\text { Median mRNA level } \\
\text { in copies/copies RPII }\end{array}$ & P-value \\
\hline OPN & $\begin{array}{l}\text { Adjacent } \\
\text { Tumour }\end{array}$ & $\begin{array}{l}49.96 \pm 59.54 \\
148.0 \pm 147.4\end{array}$ & $\begin{array}{r}16.530 \\
100.700\end{array}$ & 0.061 \\
\hline HIF-1 $\alpha$ & $\begin{array}{l}\text { Adjacent } \\
\text { Tumour }\end{array}$ & $\begin{array}{l}57.51 \pm 35.78 \\
133.2 \pm 129.7\end{array}$ & $\begin{array}{l}35.780 \\
74.800\end{array}$ & 0.083 \\
\hline HIF- $2 \alpha$ & $\begin{array}{l}\text { Adjacent } \\
\text { Tumour }\end{array}$ & $\begin{array}{l}0.832 \pm 0.293 \\
1.532 \pm 0.962\end{array}$ & $\begin{array}{l}0.825 \\
1.393\end{array}$ & $0.035^{\mathrm{a}}$ \\
\hline CA9 & $\begin{array}{l}\text { Adjacent } \\
\text { Tumour }\end{array}$ & $\begin{array}{l}0.001 \pm 0.001 \\
0.056 \pm 0.082\end{array}$ & $\begin{array}{l}0.001 \\
0.026\end{array}$ & $<0.001^{\mathrm{a}}$ \\
\hline GLUT-1 & $\begin{array}{l}\text { Adjacent } \\
\text { Tumour }\end{array}$ & $\begin{array}{l}0.249 \pm 0.072 \\
0.396 \pm 0.288\end{array}$ & $\begin{array}{l}0.249 \\
0.334\end{array}$ & 0.225 \\
\hline VEGF & $\begin{array}{l}\text { Adjacent } \\
\text { Tumour }\end{array}$ & $\begin{array}{l}0.181 \pm 0.224 \\
1.875 \pm 1.772\end{array}$ & $\begin{array}{l}0.094 \\
1.349\end{array}$ & $<0.001^{\mathrm{a}}$ \\
\hline Survivin & $\begin{array}{l}\text { Adjacent } \\
\text { Tumour }\end{array}$ & $\begin{array}{r}9.41 \pm 10.98 \\
23.23 \pm 22.25\end{array}$ & $\begin{array}{r}5.600 \\
14.440\end{array}$ & 0.057 \\
\hline EGFR & $\begin{array}{l}\text { Adjacent } \\
\text { Tumour }\end{array}$ & $\begin{array}{l}32.37 \pm 51.82 \\
308.9 \pm 745.8\end{array}$ & $\begin{array}{r}3.360 \\
12.460\end{array}$ & 0.188 \\
\hline hTERT & $\begin{array}{l}\text { Adjacent } \\
\text { Tumour }\end{array}$ & $\begin{array}{l}0.001 \pm 0.001 \\
0.006 \pm 0.010\end{array}$ & $\begin{array}{l}0.001 \\
0.002\end{array}$ & $0.049^{\mathrm{a}}$ \\
\hline Nanog & $\begin{array}{l}\text { Adjacent } \\
\text { Tumour }\end{array}$ & $\begin{array}{l}0.006 \pm 0.053 \\
0.025 \pm 0.043\end{array}$ & $\begin{array}{l}0.003 \\
0.008\end{array}$ & 0.066 \\
\hline OCT4 & $\begin{array}{l}\text { Adjacent } \\
\text { Tumour }\end{array}$ & $\begin{array}{l}0.023 \pm 0.026 \\
0.088 \pm 0.150\end{array}$ & $\begin{array}{l}0.012 \\
0.030\end{array}$ & $0.025^{\mathrm{a}}$ \\
\hline
\end{tabular}

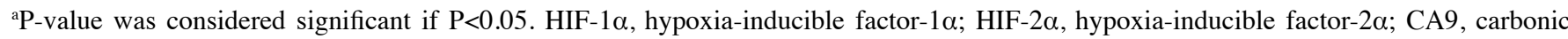
anhydrase 9; VEGF, vascular endothelial growth factor; GLUT-1, glucose transporter-1; OPN, osteopontin; EGFR, epidermal growth factor receptor; hTERT, human telomerase reverse transcriptase; OCT4, octamer-binding transcription factor 4.

In addition, higher mRNA expression levels of VEGF $(\mathrm{P}=0.016)$ and GLUT-1 $(\mathrm{P}=0.016)$ were detected in older patients compared to younger patients. The median age of patients with low mRNA expression levels of $\operatorname{VEGF}(\mathrm{P}=0.016)$ and GLUT-1 were 9 or 5 years less compared to those patients who had high mRNA transcript levels in their tumours. Based on the median, neither gender nor age showed a significant association with clinical outcome. However, younger patients with an age $\leq 60$ years $(n=10)$ lived longer than patients older than 60 years $(\mathrm{P}=0.050)$. In addition, male patients were 9 years younger than female patients $(\mathrm{P}=0.023)$.

Kaplan-Meier analyses showed a significant decrease in the overall survival time for glioblastoma patients without radiotherapy and/or chemotherapy $(\mathrm{P}<0.001)$. Only 2 of the 9 glioblastoma patients with high mRNA expression levels of hypoxia-associated genes CA9, HIF- $2 \alpha$, GLUT-1 and OPN were treated with radiotherapy and chemotherapy. On the other hand, 16 of the 25 remaining patients (64\%) received radiotherapy and chemotherapy $(\mathrm{P}=0.052)$. Based on the median levels, glioblastoma patients with high mRNA expression levels of hypoxia-associated genes showed a trend towards shorter survival time. The median survival time of glioblastoma patients with combined high mRNA expression levels of the hypoxia-associated genes CA9, HIF-2 $\alpha$, GLUT-1 and OPN ( $\mathrm{n}=9$ ) was 1.8 months (95\% CI, 1.7-1.9 months) vs. 10.1 months $(95 \% \mathrm{CI}, 8.1-12.1$ months, $\mathrm{P}=0.061)$ in the remaining patients $(\mathrm{n}=25)$. The risk of an early tumour-related death in patients with high mRNA expression levels of CA9, HIF-2 $\alpha$, GLUT-1 and OPN was 2.13 (P=0.067) (Fig. 1).

\section{Discussion}

Hypoxia is a negative prognostic factor in solid tumours including malignant gliomas. A hypoxic microenvironment may promote the self-renewal capability of glioma cells towards a stem cell-like phenotype (8). We analysed mRNA expression levels of different hypoxia-induced and stem cell-associated markers in tumour tissues from 34 patients with glioblastoma. Compared with tumour adjacent brain tissues, the mRNA expression levels of the hypoxia-induced genes HIF-2 $\alpha$, CA9 and VEGF were expressed at a significantly higher level in the tumour tissues (Table III). Our findings are in agreement with the results of our previous study. In our previous study, we examined a limited number of other glioblastomas and 
Table IV. Bivariate correlation analysis between mRNA expression levels of hypoxia-induced and stem cell-associated genes in the glioblastomas.

\begin{tabular}{|c|c|c|c|c|c|c|c|c|c|c|c|}
\hline & & \multicolumn{5}{|c|}{ Hypoxia-induced genes } & \multicolumn{5}{|c|}{ Stem cell-associated genes } \\
\hline & & HIF- $2 \alpha$ & VEGF & CA9 & GLUT-1 & OPN & EGFR & Survivin & hTERT & OCT4 & Nanog \\
\hline \multirow[t]{2}{*}{$\mathrm{HIF}-1 \alpha$} & cor & 0.458 & -0.015 & 0.226 & 0.264 & 0.130 & 0.617 & 0.617 & 0.057 & -0.082 & -0.161 \\
\hline & $\mathrm{P}$ & $0.007^{\mathrm{a}}$ & 0.931 & 0.198 & 0.132 & 0.465 & $<0.001^{\mathrm{a}}$ & $<0.001^{\mathrm{a}}$ & 0.749 & 0.643 & 0.363 \\
\hline \multirow[t]{2}{*}{ HIF- $2 \alpha$} & cor & & 0.407 & 0.595 & 0.692 & 0.518 & 0.354 & 0.309 & 0.048 & 0.006 & -0.109 \\
\hline & $\mathrm{P}$ & & $0.017^{\mathrm{a}}$ & $<0.001^{\mathrm{a}}$ & $<0.001^{\mathrm{a}}$ & $0.002^{\mathrm{a}}$ & $0.040^{\mathrm{a}}$ & 0.075 & 0.786 & 0.971 & 0.540 \\
\hline \multirow[t]{2}{*}{ VEGF } & cor & & & 0.749 & 0.696 & 0.451 & -0.063 & 0.091 & 0.176 & 0.281 & 0.256 \\
\hline & $\mathrm{P}$ & & & $<0.001^{\mathrm{a}}$ & $<0.001^{\mathrm{a}}$ & $0.007^{\mathrm{a}}$ & 0.722 & 0.609 & 0.320 & 0.108 & 0.144 \\
\hline \multirow[t]{2}{*}{ CA9 } & cor & & & & 0.843 & 0.619 & 0.165 & 0.083 & 0.008 & -0.005 & -0.110 \\
\hline & $\mathrm{P}$ & & & & $<0.001^{\mathrm{a}}$ & $<0.001^{\mathrm{a}}$ & 0.350 & 0.641 & 0.964 & 0.976 & 0.536 \\
\hline \multirow[t]{2}{*}{ GLUT-1 } & cor & & & & & 0.610 & 0.275 & 0.167 & 0.070 & 0.003 & -0.033 \\
\hline & $\mathrm{P}$ & & & & & $<0.001^{\mathrm{a}}$ & 0.115 & 0.344 & 0.695 & 0.985 & 0.855 \\
\hline \multirow[t]{2}{*}{ OPN } & cor & & & & & & -0.014 & 0.241 & -0.115 & 0.076 & 0.064 \\
\hline & $\mathrm{P}$ & & & & & & 0.938 & 0.169 & 0.519 & 0.671 & 0.719 \\
\hline \multirow[t]{2}{*}{ EGFR } & cor & & & & & & & 0.400 & -0.001 & 0.026 & 0.008 \\
\hline & $\mathrm{P}$ & & & & & & & $0.019^{\mathrm{a}}$ & 0.994 & 0.882 & 0.966 \\
\hline \multirow[t]{2}{*}{ Survivin } & cor & & & & & & & & 0.098 & 0.153 & 0.147 \\
\hline & $\mathrm{P}$ & & & & & & & & 0.582 & 0.389 & 0.408 \\
\hline \multirow[t]{2}{*}{ hTERT } & cor & & & & & & & & & 0.168 & 0.217 \\
\hline & $\mathrm{P}$ & & & & & & & & & 0.343 & 0.218 \\
\hline \multirow[t]{2}{*}{ OCT4 } & cor & & & & & & & & & & 0.939 \\
\hline & $\mathrm{P}$ & & & & & & & & & & $<0.001^{\mathrm{a}}$ \\
\hline
\end{tabular}

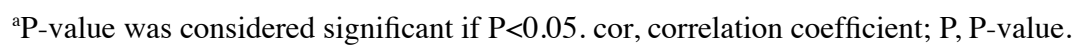

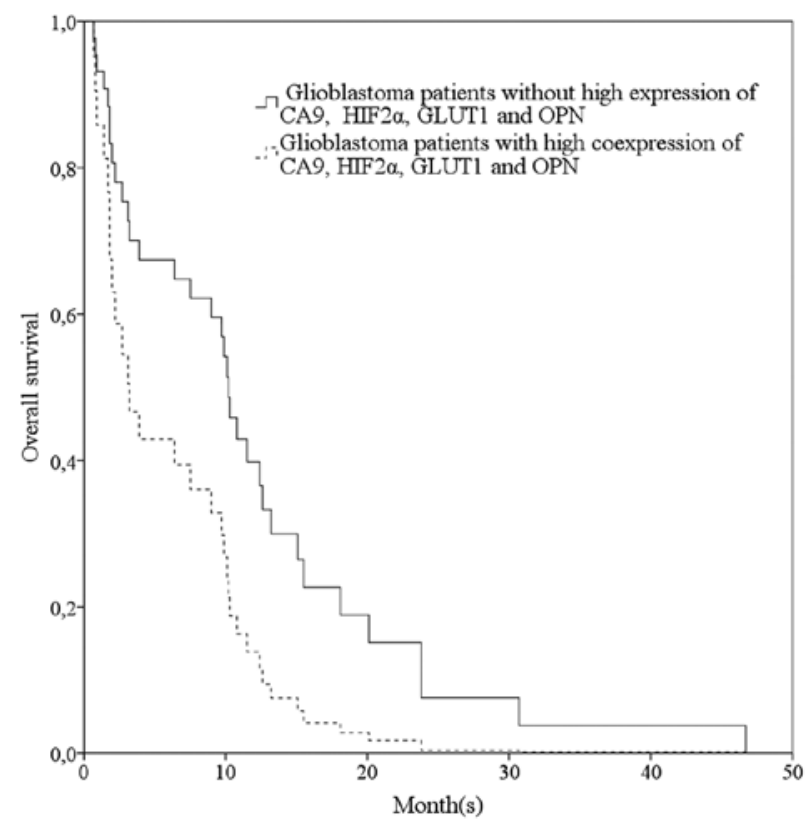

Figure 1. mRNA expression levels of hypoxia-associated genes and overall survival time of glioblastoma patients. Based on the median transcript levels, glioblastoma patients with combined high mRNA expression levels of the hypoxia-associated markers CA9, HIF-2 $\alpha$, GLUT-1 and OPN (dotted line) had, on average, a shorter survival time than the remaining patients (bold line) using a univariate Cox's proportional-hazards regression model. Patients whose tumours weakly expressed hypoxia-associated markers had a 2.13 -fold lower risk of an early tumour-related death than patients with high expression of hypoxia-associated markers in their tumours $(\mathrm{P}=0.067)$.

detected high mRNA expression levels of HIF-1 $\alpha$, CA9, VEGF and erythropoietin (26). Several other studies have reported higher mRNA expression levels of different hypoxia-induced genes in tissues of glioblastomas compared with low-grade astrocytoma or tumour adjacent tissue (27-30). Other studies detected high mRNA expression levels of stem-cell genes in 
malignant glioma compared with surrounding non-tumour tissue (31-35). Our study confirmed these results for the analysed stem cell-associated genes, hTERT and OCT4.

Our analysis showed a strong correlation of expression levels for hypoxia-induced genes with each other. However, the HIF-1 $\alpha$ mRNA level was only partially associated with other hypoxia-induced genes. In addition, the transcript levels of hypoxia-induced genes were also significantly associated with high OPN and EGFR mRNA levels in the glioblastoma (Table IV). We previously showed that higher plasma OPN values were detected in glioma patients with larger and more necrotic tumours (36). In addition, a significant association between mRNA expression levels of both hypoxia-induced genes HIF- $1 \alpha$ and HIF- $2 \alpha$ with the stem cell-related gene EGFR was observed. We also found an association between the expression of HIF-1 $\alpha$ and survivin. In patients with glioblastoma, a stem cell-related 'self-renewal' signature was found to be associated with high EGFR expression and therapeutic resistance (37). In vitro analyses showed an upregulation of survivin in neuronal and cancer stem cells $(21,38)$. The role of survivin by hypoxia in tumour cells is controversial. However, there is also a link between HIF-1 $\alpha$, survivin and EGFR expression in breast cancer cell lines (39). In addition an association between hypoxia-activated EGFR signaling and the epithelial-to-mesenchymal transition in the epithelial cancer cell line A431 was described (40). Our results suggest that a hypoxia-induced mRNA profile is associated with the expression of stem cell-related genes in glioblastoma tissues. However, the stem cell-associated genes hTERT, OCT4 and Nanog showed no significant association with the expression levels of hypoxia-induced markers. These results indicate that the role of stem cell-related genes in tumour hypoxia should be examined more closely in future studies.

Several studies have demonstrated that higher protein levels of single hypoxia-induced genes correlate positively with malignancy and shorter survival in glioma patients (41-46). However, the prognostic impact is less obvious for hypoxia-induced genes at the mRNA expression level. VEGF but not EGFR, has been shown to be an independent prognostic marker in 86 patients with astrocytic malignant gliomas (30). A study in glioma patients demonstrated that low VEGF mRNA levels were associated with a favourable outcome, but they were not an independent factor in a multivariate analysis (27). However, another study in patients with astrocytoma showed that co-expression of EGFR, IGFBP-2 and HIF-2 $\alpha$ were independent prognostic factors (28). This is in agreement with our analysis, which showed that glioblastoma patients with high mRNA expression of CA9, HIF-2 $\alpha$, GLUT-1 and OPN had the shortest median survival time of 1.8 months. Due to the limited patient number in this study, the high co-expression of hypoxia-induced genes showed only a trend of shorter overall survival. Several studies have shown that mRNA expression levels of stem cell markers also predict clinical outcomes and therapy resistance in patients with glioblastoma multiforme (37,47-49). Consistent with these results, the in vitro growth potential of patient cancer stem cells correlated with shorter overall and progression-free survival in glioblastoma patients (50). However, in our analysis, the stem cell-associated genes survivin, EGFR, hTERT, Nanog and OCT4 showed no significant association with overall survival. It is possible that protein expression of the analysed stem cell-related genes is more closely associated with survival than mRNA expression.

In summary, in the present study, we detected a link between mRNA levels of hypoxia-induced and stem cell-associated genes in glioblastoma tissues. Both gene groups were expressed at higher levels in glioblastomas than in the tumour adjacent tissues. Notably, elevated mRNA expression levels of hypoxia-induced genes resulted in shorter survival times for glioblastoma patients. Our findings suggest that mRNA expression levels of hypoxia-induced and stem cell-associated genes are important markers in patients with glioblastoma multiforme. However, further prospective studies with a larger number of patients are necessary to support our findings.

\section{Acknowledgements}

This study was supported by the Wilhelm Sander Stiftung (grant no. 2013.090.1). We thank Gabriele Thomas from the Department of Radiotherapy, University of Halle, for her excellent technical assistance. We are thankful to Dr P. Schmidt/Tumorzentrum Martin Luther University Halle-Wittenberg for his help with the follow-up data. We would like to thank the American Journal Experts for the language editing of our manuscript.

\section{References}

1. Henriksson R, Asklund T and Poulsen HS: Impact of therapy on quality of life, neurocognitive function and their correlates in glioblastoma multiforme: a review. J Neurooncol 104: 639-646, 2011.

2. Nieder C and Mehta MP: Advances in translational research provide a rationale for clinical re-evaluation of high-dose radiotherapy for glioblastoma. Med Hypotheses 76: 410-413, 2011.

3. Shirai $\mathrm{K}$ and Chakravarti A: Towards personalized therapy for patients with glioblastoma. Expert Rev Anticancer Ther 11: 1935-1944, 2011.

4. Graeber TG, Osmanian C, Jacks T, Housman DE, Koch CJ, Lowe SW and Giaccia AJ: Hypoxia-mediated selection of cells with diminished apoptotic potential in solid tumours. Nature 379: 88-91, 1996.

5. Bristow RG and Hill RP: Hypoxia and metabolism. Hypoxia, DNA repair and genetic instability. Nat Rev Cancer 8: 180-192, 2008.

6. Collingridge DR, Piepmeier JM, Rockwell S and Knisely JP: Polarographic measurements of oxygen tension in human glioma and surrounding peritumoural brain tissue. Radiother Oncol 53: 127-131, 1999.

7. Bar EE: Glioblastoma, cancer stem cells and hypoxia. Brain Pathol 21: 119-129, 2011.

8. Heddleston JM, Li Z, McLendon RE, Hjelmeland AB and Rich JN: The hypoxic microenvironment maintains glioblastoma stem cells and promotes reprogramming towards a cancer stem cell phenotype. Cell Cycle 8: 3274-3284, 2009.

9. McCord AM, Jamal M, Shankavaram UT, Lang FF, Camphausen K and Tofilon PJ: Physiologic oxygen concentration enhances the stem-like properties of $\mathrm{CD} 33^{+}$human glioblastoma cells in vitro. Mol Cancer Res 7: 489-497, 2009.

10. Seidel S, Garvalov BK, Wirta V, von Stechow L, Schänzer A, Meletis K, Wolter M, Sommerlad D, Henze AT, Nistér M, et al: A hypoxic niche regulates glioblastoma stem cells through hypoxia inducible factor 2 alpha. Brain 133: 983-995, 2010.

11. Kolenda J, Jensen SS, Aaberg-Jessen C, Christensen K, Andersen C, Brünner N and Kristensen BW: Effects of hypoxia on expression of a panel of stem cell and chemoresistance markers in glioblastoma-derived spheroids. J Neurooncol 103: 43-58, 2011.

12. Vordermark D and Brown JM: Endogenous markers of tumor hypoxia predictors of clinical radiation resistance? Strahlenther Onkol 179: 801-811, 2003. 
13. Bache M, Kappler M, Said HM, Staab A and Vordermark D Detection and specific targeting of hypoxic regions within solid tumors: Current preclinical and clinical strategies. Curr Med Chem 15: 322-338, 2008

14. Dahlrot RH, Hermansen SK, Hansen S and Kristensen BW: What is the clinical value of cancer stem cell markers in gliomas? Int J Clin Exp Pathol 6: 334-348, 2013.

15. Haar CP, Hebbar P, Wallace GC IV, Das A, Vandergrift WA III, Smith JA, Giglio P, Patel SJ, Ray SK and Banik NL: Drug resistance in glioblastoma: a mini review. Neurochem Res 37: 1192-1200, 2012

16. Tanaka S, Louis DN, Curry WT, Batchelor TT and Dietrich J: Diagnostic and therapeutic avenues for glioblastoma: no longer a dead end? Nat Rev Clin Oncol 10: 14-26, 2013.

17. Dreyfuss JM, Johnson MD and Park PJ: Meta-analysis of glioblastoma multiforme versus anaplastic astrocytoma identifies robust gene markers. Mol Cancer 8: 71, 2009.

18. Jin F, Zhao L, Zhao HY, Guo SG, Feng J, Jiang XB, Zhang SL, Wei YJ, Fu R and Zhao JS: Comparison between cells and cancer stem-like cells isolated from glioblastoma and astrocytoma on expression of anti-apoptotic and multidrug resistance-associated protein genes. Neuroscience 154: 541-550, 2008

19. Casalbore P, Budoni M, Ricci-Vitiani L, Cenciarelli C, Petrucci G, Milazzo L, Montano N, Tabolacci E, Maira G, Larocca LM, et al: Tumorigenic potential of olfactory bulb-derived human adult neural stem cells associates with activation of TERT and NOTCH1. PLoS One 4: e4434, 2009.

20. Acquati S, Greco A, Licastro D, Bhagat H, Ceric D, Rossini Z, Grieve J, Shaked-Rabi M, Henriquez NV, Brandner S, et al: Epigenetic regulation of survivin by Bmil is cell type specific during corticogenesis and in gliomas. Stem Cells 31: 190-202, 2013.

21. Guvenc H, Pavlyukov MS, Joshi K, Kurt H, BanasavadiSiddegowda YK, Mao P, Hong C, Yamada R, Kwon CH Bhasin D, et al: Impairment of glioma stem cell survival and growth by a novel inhibitor for Survivin-Ran protein complex. Clin Cancer Res 19: 631-642, 2013.

22. Mao XG, Hütt-Cabezas M, Orr BA, Weingart M, Taylor I, Rajan AK, Odia Y, Kahlert U, Maciaczyk J, Nikkhah G, et al: LIN28A facilitates the transformation of human neural stem cells and promotes glioblastoma tumorigenesis through a pro-invasive genetic program. Oncotarget 4: 1050-1064, 2013.

23. Paul I, Bhattacharya S, Chatterjee A and Ghosh MK: Current understanding on EGFR and Wnt/ $\beta$-catenin signaling in glioma and their possible crosstalk. Genes Cancer 4: 427-446, 2013.

24. Söling A, Plugge EM, Schmitz M, Weigle B, Jacob R, Illert J, Holzhausen HJ and Rainov NG: Autoantibodies to the inhibitor of apoptosis protein survivin in patients with brain tumors. Int $\mathrm{J}$ Oncol 30: 123-128, 2007.

25. Bache M, Kappler M, Wichmann H, Rot S, Hahnel A, Greither T, Said HM, Kotzsch M, Würl P, Taubert H, et al: Elevated tumor and serum levels of the hypoxia-associated protein osteopontin are associated with prognosis for soft tissue sarcoma patients. BMC Cancer 10: 132, 2010

26. Said HM, Hagemann C, Staab A, Stojic J, Kühnel S, Vince GH, Flentje M, Roosen K and Vordermark D: Expression patterns of the hypoxia-related genes osteopontin, CA9, erythropoietin, VEGF and HIF-1alpha in human glioma in vitro and in vivo. Radiother Oncol 83: 398-405, 2007.

27. Søndergaard KL, Hilton DA, Penney M, Ollerenshaw M and Demaine AG: Expression of hypoxia-inducible factor 1alpha in tumours of patients with glioblastoma. Neuropathol Appl Neurobiol 28: 210-217, 2002.

28. Zhou YH, Tan F, Hess KR and Yung WK: The expression of PAX6, PTEN, vascular endothelial growth factor, and epidermal growth factor receptor in gliomas: relationship to tumor grade and survival. Clin Cancer Res 9: 3369-3375, 2003.

29. Nam DH, Park K, Suh YL and Kim JH: Expression of VEGF and brain specific angiogenesis inhibitor-1 in glioblastoma: Prognostic significance. Oncol Rep 11: 863-869, 2004.

30. Scrideli CA, Carlotti CG Jr, Mata JF, Neder L, Machado HR, Oba-Sinjo SM, Rosemberg S, Marie SK and Tone LG: Prognostic significance of co-overexpression of the EGFR/IGFBP-2/HIF-2A genes in astrocytomas. J Neurooncol 83: 233-239, 2007

31. Kajiwara Y, Yamasaki F, Hama S, Yahara K, Yoshioka H, Sugiyama K, Arita K and Kurisu K: Expression of survivin in astrocytic tumors: correlation with malignant grade and prognosis. Cancer 97: 1077-1083, 2003.

32. Ma YH, Mentlein R, Knerlich F, Kruse ML, Mehdorn HM and Held-Feindt J: Expression of stem cell markers in human astrocytomas of different WHO grades. J Neurooncol 86: 31-45, 2008
33. Sun G, Wang Y, Sun L, Luo H, Liu N, Fu Z and You Y: Clinical significance of Hiwi gene expression in gliomas. Brain Res 1373: 183-188, 2011.

34. Yoshimoto K, Ma X, Guan Y, Mizoguchi M, Nakamizo A, Amano T, Hata N, Kuga D and Sasaki T: Expression of stem cell marker and receptor kinase genes in glioblastoma tissue quantified by real-time RT-PCR. Brain Tumor Pathol 28: 291-296, 2011.

35. Wang L, He S, Yuan J, Mao X, Cao Y, Zong J, Tu Y and Zhang Y: Oncogenic role of SOX9 expression in human malignant glioma. Med Oncol 29: 3484-3490, 2012.

36. Güttler A, Giebler M, Cuno P, Wichmann H, Kessler J, Ostheimer C, Söling A, Strauss C, Illert J, Kappler M, et al: Osteopontin and splice variant expression level in human malignant glioma: radiobiologic effects and prognosis after radiotherapy. Radiother Oncol 108: 535-540, 2013.

37. Murat A, Migliavacca E, Gorlia T, Lambiv WL, Shay T, Hamou MF, de Tribolet N, Regli L, Wick W, Kouwenhoven MC, et al: Stem cell-related 'self-renewal' signature and high epidermal growth fact or receptor expression associated with resistance to concomitant chemoradiotherapy in glioblastoma. J Clin Oncol 26: 3015-3024, 2008.

38. Feng R, Zhou S, Liu Y, Song D, Luan Z, Dai X, Li Y, Tang N, Wen J and Li L: Sox 2 protects neural stem cells from apoptosis via up-regulating survivin expression. Biochem J 450: 459-468, 2013.

39. Peng XH, Karna P, Cao Z, Jiang BH, Zhou $M$ and Yang L: Cross-talk between epidermal growth factor receptor and hypoxia-inducible factor-1alpha signal pathways increases resistance to apoptosis by up-regulating survivin gene expression. J Biol Chem 281: 25903-25914, 2006.

40. Misra A, Pandey C, Sze SK and Thanabalu T: Hypoxia activated EGFR signaling induces epithelial to mesenchymal transition (EMT). PLoS One 7: e49766, 2012.

41. Korkolopoulou P, Patsouris E, Konstantinidou AE, Pavlopoulos PM, Kavantzas N, Boviatsis E, Thymara I, Perdiki M, Thomas-Tsagli E, Angelidakis D, et al: Hypoxia-inducible factor 1alpha/vascular endothelial growth factor axis in astrocytomas. Associations with microvessel morphometry, proliferation and prognosis. Neuropathol Appl Neurobiol 30: 267-278, 2004.

42. Flynn JR, Wang L, Gillespie DL, Stoddard GJ, Reid JK, Owens J, Ellsworth GB, Salzman KL, Kinney AY and Jensen RL: Hypoxia-regulated protein expression, patient characteristics, and preoperative imaging as predictors of survival in adults with glioblastoma multiforme. Cancer 113: 1032-1042, 2008

43. Sathornsumetee S, Cao Y, Marcello JE, Herndon JE II, McLendon RE, Desjardins A, Friedman HS, Dewhirst MW, Vredenburgh JJ and Rich JN: Tumor angiogenic and hypoxic profiles predict radiographic response and survival in malignant astrocytoma patients treated with bevacizumab and irinotecan. J Clin Oncol 26: 271-278, 2008.

44. Hofstetter CP, Burkhardt JK, Shin BJ, Gürsel DB, Mubita L, Gorrepati R, Brennan C, Holland EC and Boockvar JA: Protein phosphatase 2A mediates dormancy of glioblastoma multiforme-derived tumor stem-like cells during hypoxia. PLoS One 7: e30059, 2012.

45. Proescholdt MA, Merrill MJ, Stoerr EM, Lohmeier A, Pohl F and Brawanski A: Function of carbonic anhydrase IX in glioblastoma multiforme. Neuro Oncol 14: 1357-1366, 2012.

46. Erpolat OP, Gocun PU, Akmansu M, Ozgun G and Akyol G: Hypoxia-related molecules HIF-1 $\alpha$, CA9, and osteopontin: predictors of survival in patients with high-grade glioma. Strahlenther Onkol 189: 147-154, 2013.

47. He J, Shan Z, Li L, Liu F, Liu Z, Song M and Zhu H: Expression of glioma stem cell marker CD133 and $O^{6}$-methylguanine-DNA methyltransferase is associated with resistance to radiotherapy in gliomas. Oncol Rep 26: 1305-1313, 2011.

48. Metellus $\mathrm{P}$, Nanni-Metellus I, Delfino C, Colin C, Tchogandjian A, Coulibaly B, Fina F, Loundou A, Barrie M, Chinot $\mathrm{O}$, et al: Prognostic impact of CD133 mRNA expression in 48 glioblastoma patients treated with concomitant radiochemotherapy: a prospective patient cohort at a single institution. Ann Surg Oncol 18: 2937-2945, 2011.

49. Nakata S, Campos B, Bageritz J, Bermejo JL, Becker N, Engel F, Acker T, Momma S, Herold-Mende C, Lichter P, et al: LGR5 is a marker of poor prognosis in glioblastoma and is required for survival of brain cancer stem-like cells. Brain Pathol 23: 60-72, 2013.

50. Pallini R, Ricci-Vitiani L, Banna GL, Signore M, Lombardi D, Todaro M, Stassi G, Martini M, Maira G, Larocca LM, et al: Cancer stem cell analysis and clinical outcome in patients with glioblastoma multiforme. Clin Cancer Res 14: 8205-8212, 2008. 